\title{
The Mortgage Crisis: Government Intervention And Debtors' Options
}

Anand Shetty, Iona College, USA

Steven L. Kroleski, Iona College, USA

\begin{abstract}
The real estate market crash was a major contributor in creating the dismal global economic situation. The paper reviews the options of the homeowners in debt and the government's actions to stimulate the real estate market.
\end{abstract}

Keywords: mortgage, foreclosure, forebearance agreement, deed in lieu of foreclosure, bankruptcy, loan modification agreements, short sales

\section{INTRODUCTION}

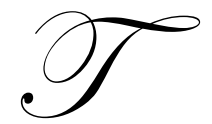

he bottom line is that defaults in mortgage payments are steadily increasing, and without immediate assistance from the Federal government, judiciary, and the lending institutions, the future is bleak. Home values will continue to decline, resulting in a loss in the equity in homes, displacement of homeowners and their families, and significant monetary losses to the lenders, which would mean that they will be hesitant to lend monies to homeowners in the future.

The mortgage crisis was the result of anxious lenders and borrowers motivated by either greed, or ignorance, and/or both. These parties were facilitated by mortgage brokers, real estate brokers and real estate appraisers, all playing an active roll in the collapse of the real estate market and the values of our homes. For most of us, our biggest asset is our home, especially with the virtual collapse of the stock market and all of our retirement investments taking a downward dip. Countless homeowners, who were financially responsible, were adversely affected through no fault of their own in that the value of their homes decreased in value. Also, these people if now confronted with home repairs, college tuitions, etc. are again affected because they now cannot refinance to pay for these expenses due to the fact there is no longer substantial equity in their homes and because the refinance requirements have tightened up. Now, for example, many lending institutions will not permit the homeowner to refinance if he/she owes more than $80 \%$ of the now devalued property.

Canada did not suffer from the crisis as did their neighbors to the south, because they used good common business sense, which ultimately proved successful for both the lenders and the homeowners. The lenders required the borrowers to have $25 \%$ of the purchase price in hand when seeking a loan. In this way, the lender had a lesser risk factor should the loan default, or the value of the property decrease, and the borrowers had a substantial investment in their home so that they would do all in their power to make payments and save their home/investment. In the United States, through sellers' concessions and taking out lines of credit at the real estate closings, the borrowers were receiving, at times, $100 \%$ of the sales price at closing, if not more. Then, should the interest rates increase, the debtors lose their employment, or taxes increase, etc., the debtors found themselves defaulting without any reserve monies and without any real investment in the residence. This resulted in substantial defaults on home loans accompanied by huge decreases in the value of the properties, generally between ten and fifty percent. This places the lenders in no-win situations because the debtors borrowed more money than the value of the properties; so if the banks prevail in the foreclosure proceedings, they become the owners of devalued property, only to resell the premises at further losses. There are estimated to be between 5 and 7 million foreclosures in the next several years, especially with the increased unemployment/lay-off trend and the outsourcing of jobs. The National Association of Realtors has shown that the last four months (thru July of 2009) have resulted in monthly sales increases. This is not believed to be a turnaround in the market, but a holding pattern with still worse to come. Four states have accounted for $44 \%$ of the new foreclosures; i.e. California, Nevada, Arizona and Florida. 
When purchasing a home, the debtors execute a mortgage, which is a legal document used to pledge real property (real estate) to secure a debt (generally a loan to purchase or refinance the property). Together with the mortgage, the debtors execute a note, which is a legally binding promise to pay back the borrowed money. Should a default occur, the lenders have the opportunity of suing either on the note or, in the alternative, commencing foreclosure proceedings in order to take back the homes. Once in default, the debtors have many options, as follows:

1. Seek financial assistance from relatives. This is why you should marry for money and not love. Love is a good thing, but it won't pay the mortgage. However, the global economic crisis has made this option less available.

2. $\quad$ Refinance the property, which is a conventional remedy .The problem with this option is that the lenders will only allow you to refinance a certain percentage of the property (generally up to $80 \%$ of the value). The debtors owe more than the value of the properties between the high loans and the substantial decreases in the value of the properties, making this option virtually non-existent for many. It should be noted, however, that the President is seeking to allow debtors the opportunity to borrow over $100 \%$ of the fair market value of their primary residences. This very same lending practice contributed to the very mortgage crisis that we are now confronted with.

3. Do nothing. Some debtors see no real relief in sight, so they continue to reside at the premises without making mortgage, tax and insurance payments. These parties could stay there for many months accumulating all of these monies saved by virtue of not making payments, then use these monies to rent an apartment or other residence once evicted by the Courts.

4. Some debtors elect to enter into a forbearance agreement. This agreement provides that the lender will not commence or not continues to pursue a foreclosure action in exchange for the debtor fulfilling his/her promises. The debtor's promises could be to consent to the amount owed, a deed in lieu of foreclosure at a set date (discussed below), a refinance, a pending sale, etc.

5. Some debtors elect to give the lenders a deed in lieu of foreclosure. This is a quick process and with today's foreclosure epidemic, probably one of the most practical, although not being used as much as it should. Simply put, the borrowers gives back the properties to the lenders by deed, without the necessary expense and time involved in commencing foreclosure proceedings. In turn, the lenders agree not to seek deficiency judgments against the borrowers. A deficiency judgment is when the lenders take back the properties and thereafter sell them, seeking to recover all of the money to which they are entitled. If, upon the sale, the proceeds fall short of the monies owed, then the lenders seek this deficiency from the borrowers.

The next three options are the most popular today, so each are discussed in a little more detail:

6. Some debtors elect to go bankrupt. The protection generally sought is in Chapter 13 proceedings, which has the power to automatically stay all legal actions against the debtors, including foreclosure proceedings. The problem is that this chapter enacted to give debtors financial relief and a new economic life is limited by its own creation. Within the Act, specifically 11U.S.C, Sect. 1322 (b), (1), Chapter 13 plans cannot modify the rights of the holders of claims secured by interests in real property (lenders holding mortgages). The history behind the passage of this Act was to protect the lenders who were permitting persons to be homeowners. (2) In fact, the Supreme Court of the United States in the Nobleman case stated: "favorable treatment of residential mortgages was intended to encourage the flow of capital into the home lending market." (3) In simple language, this means that the Bankruptcy Judge cannot rewrite the loan. For example, if a debtor owed $\$ 250,000.00$ on his/her home, and the value of the home was now worth $\$ 200,000.00$, the Judge does not have the ability to reduce the loan to coincide with the value of the property. If the Judge did have the power to do so, the Judge could reduce the loan to $\$ 200,000.00$ and along with it, the mortgage payments by $20 \%$ to reflect the decrease in the loan. This sounds like a practical solution; however, this unilateral action by the Court would destroy the general principals of contract law which as of now, violate the Bankruptcy Code. There were bills floating around Congress attempting to amend the Bankruptcy Code so that the Court would have the power to rewrite contracts. They will both probably be squashed in the Senate, which in these authors' opinions, is a good thing. The reason for the limitation on the power of the Court was initially to encourage the lending institutions to make more loans so that people could own their own homes, etc. and, at the same time, protect the bank by giving them a secured loan in the event of a default. They would then, in theory, collect all of their monies and not sustain any losses. This procedure 
worked successfully for years when the cash was flowing and the values of the houses kept rising year in and year out. But then appeared reality, the unexpected and not planned for - the global economic meltdown. The system by which monies were loaned in the past was shown to be a formula for disaster. The government's involvement now could too be disasterous if not accomplished with sound economic principles. The government enacted the American Recovery and Reinstatement Act of 2009 to assist firsttime buyers with an $\$ 8,000.00$ credit as an incentive to purchase. (4)

7. Loan Modification Agreements are becoming the most popular and practical remedy available for both the Lender and the Debtor. Many States are requiring the Lender and Debtor to negotiate and/or mediate a resolution before permitting the foreclosure proceeding to proceed. In New York state, a settlement conference is common practice as a part of the foreclosure proceeding. A typical outcome would be that the Lender ultimately receives payment, but in exchange, it must reduce the interest rate or lower the amount due, or some type of combination whereby payments are smaller now, but loaded on to the back end of the loan. This type of settlement is contingent upon the Debtor keeping current with the new payment schedule. Many Federal Courts are requiring Loss Mitigation Conferences with the same types of resolutions. The goal is to keep the Debtor in his/her home and, at the same time, protect the Lender's investment so that it will ultimately receive payment. Further, some Court's have created a mediation process, which is a nonbinding attempt by virtue of a Court-appointed mediator to resolve the financial issues involved with the loan. The basic foreclosure proceeding will quite often result in the Lender receiving the house, but it could be subject to other liens and tax obligations. Lending institutions do not want to be the owner of surplus residences in a depressed market. So this type of negotiation process is gaining in popularity and probably makes the most sense for all.

8. Another option sought by debtors, which is becoming more popular, is that of the short sale. A short sale is an offer by the homeowner to sell his/her property for a lesser amount than is owed by him/her to the bank. The debtor, as part of the short sale, would receive full satisfaction of the debt. Thus, he/she would not be foreclosed on, have to seek bankruptcy protection and be concerned about a deficiency judgment .On the other hand, the lender avoids the time and cost of a foreclosure proceeding and doesn't become a property owner in this recessed market. Should the lender not be agreeable and instead pursue a foreclosure proceeding, the debtor could elect to file a Chapter 7 proceeding (liquidation) whereby the end result would virtually be the same for the lender. In a Chapter 7 proceeding, the lender would receive the proceeds from a sale (secured amount) and the additional monies owed by the debtor (deficiency) would be considered an unsecured loan and be wiped out in the bankruptcy proceeding anyway. The short sale buyer is in the best situation for a monetary gain from the sale. When the market values increase, and they should in the future, the purchaser would benefit from the appreciation. The short sale differs from the normal two-party contract in that besides the seller and the buyer, the lender's approval is necessary, and if more than one loan with different lenders, than the additional lenders too must approve of the sale. The approval(s) are necessary because, by virtue of the sale, the lender(s) are giving up monies that they would be entitled to in a perfect world.

Some of the short sale requirements are:

1. The debtor must be insolvent (debts exceed assets);

2. The debtor must be at least a few months in default on his/her mortgage payments;

3. The property's value must be worth less than the loan amount;

4. The debtor must illustrate a legitimate reason for the default; for example, loss of employment, divorce, illness, etc.

Initially, there was a serious downside for the seller to be involved in a short sale. The deficiency amount forgiven by the lender in the short sale was considered income to the seller and he/she would receive a 1099. If the debtor was out of work, or obviously financially strapped, it would be an impossibility to pay taxes on this newfound income. On October 7, 2007, President Bush helped pass the Mortgage Foregiveness Debt relief Act of 2007, (5) which excluded this type of income (up to $\$ 2,000,000.00$ ); also, Section 108 of the IRS Tax Code provides that the debt discharged is not taxable if the taxpayer is insolvent. 
The present government's bailout, if to minimally qualified purchasers or homeowners seeking refinancing with minimal equity in their homes, will be a temporary, but disastrous future for the real estate market. The market took a hit and should ride the tide for a while. The lenders should stiffen the requirements for loans, as opposed to, give away plans. The foreclosed homes are a loss for the banks and they could sell the same to qualified buyers based upon the new worth of the properties, with lower interest rates. The banks could than lick their wounds, but new loans would be secured by today's values and the purchasers would be better qualified. In time, the real estate market would stabilize and than the values would increase as they historically do. However, in the future, the increases would be less drastic with less chance of a downside market.

\section{CONCLUSION}

The government is passing many laws to attempt to quickly stimulate the economy. However, in reviewing the legislation passed, the government appears to be on the brink of allowing refinancing for debtors at over $100 \%$ of the current market value of their homes. This is the very type of unregulated lending that has led us into financial ruin in the first place, only now to be repeated with the government's blessings. Quick fixes, such as the money for auto clunkers, are a very short-sighted solution. That program was to last a year, but instead only lasted a few weeks. The government was ill-prepared for the rush, the dealers were not reimbursed in many cases, and the money has been quickly depleted. The same applies with housing. If the government is going to give away money for one year with the $\$ 8,000.00$ credit and/or reduce the loan requirements as the master plan for the real estate industry, the future looks bleak. Instead, the government should require some sort of mediation between all Lenders and Debtors before a foreclosure proceeding could be commenced, and further, allow the Lender tax incentives to reduce the amount of the loan. This would help alleviate the Lenders' losses and at the same time, keep the Debtors in their homes. This would prevent cash-driven investors from picking up homes at bargain basement prices to the detriment of the Lender, Debtor, entire neighborhood where the market values would come crashing down and upon the municipalities that are now being forced to reduce their real estate taxes based upon the reduced market values of all of the homes.

\section{AUTHOR INFORMATION}

Anand Shetty PhD., Professor of Finance, Hagan School of Business, Iona College.

Steven L. Kroleski Received his J.D. degree from St. John's University in 1975. He started out his legal career at Milbank, Tweed, Hadley \& McCloy in New York City. Currently he is a sole practitioner in Pelham, New York and is an Assistant Professor at Iona College in New Rochelle, New York, since 1981.

\section{REFERENCES}

1. 11 U.S.C. Section 1322 (b) provides " the plan may (2) modify the rights of holders of secured claims, other than a claim secured only by a security interest in real property that is the debtor's principal residence, or of holder of unsecured claims, or leave unaffected the rights of the holders of any class of claims."

2. $\quad$ Grubbs vs. Houston First American Sav. Assn., 730 F.2d.236 (1984).

3. $\quad$ Nobelman vs. American Sav. Bank, 508 U.S. 324, 332 (1993).

4. The American Recovery and Reinvestment Act of 2009 (also known as the stimulus package) was passed by the House of Representatives on January 28, 2009, by the Senate on February 10, 2009 and signed into law by the President on February 17, 2009. It will give first time home buyers a refundable credit of $\$ 8,000.00$ for all home purchased between January 1, 2009 and December 31, 2009. If the home owner stays at the residence for three or more years, than the credit does not have to be repaid.

5. The Mortgage Debt Relief Act of 2007, enacted on December 20, 2007, according to the Internal Revenue Service, "allows taxpayers to exclude income from the discharge of debt on their principal residence. Debt reduced through mortgage restructuring, as well as mortgage debt forgiven in connection with a foreclosure, qualifies for the relief. The provision applies to debt forgiven in calendar year 2007 through 2012. Up to $\$ 2$ million of forgiven debt is eligible for this exclusion ( $\$ 1$ million if married filing separately). 